\title{
Faktor-Faktor Yang Mempengaruhi Keberhasilan Petani Bawang Merah di Trans Tayawi Desa Koli Kecamatan Oba Kota Tidore Kepulauan
}

\author{
Nurhafni Abas ${ }^{1 *}$, Natal Basuki², Mila Fatmawati ${ }^{3}$, Haris Mahmud 4 \\ 1,2,3,4 Universitas Khairun \\ "Corresponding author: nurhafni@gmail.com
}

\begin{abstract}
Abstrak: Penelitian tentang faktor-faktor yang mempengaruhi keberhasilan petani bawang merah, dilakukan pada tanggal 23-30 Desember 2020 di Trans Tayawi Desa Koli Kecamatan Oba Kota Tidore Kepulauan dengan tujuan mengetahui faktor peran penyuluh, Motivasi petani, kemampuan diri dan pemasaran terhadap keberhasilan petani bawang merah. Metode penelitian yang digunakan adalah kuantitatif deskriptif, pengumpulan data dilakukan dengan cara informasi observasi dan penyebaran kuisioner, serta dilakukan wawancara dan studi dokumentasi. Berdasarkan pengujian data yang dilakukan secara simultan menunjukkan pengaruh sebesar $60 \%$ dan pengujian secara parsial menunjukkan tiga faktor yang berpengaruh diantaranya motivasi petani, kemampuan diri, dan pemasaran menunjukkan pengaruh signifikan $\leq$ 0,05 terhadap keberhasilan petani bawang merah, sedangkan untuk peran penyuluh tidak memberikan pengaruh secara signifikan terhadap keberhasilan petani bawang merah. Bawang merah merupakan komoditas yang potensial untuk dikembangkan di Maluku Utara.
\end{abstract}

Kata Kunci: Bawang Merah, Keberhasilan Petani

\begin{abstract}
This Research related to the factors influencing the success of onion farmers, was conducted on 23-30 December 2020 at Trans Tayawi, Koli Village, Oba Sub-district, Tidore Kepulauan City. This study aimed to determine the role of extension agents, farmer motivation, self-efficacy and marketing toward the success of onion farmers. This study used a descriptive quantitative research method, and data was collected through observation, questionnaires, interviews, and documentation studies. According to simultaneous data testing it is indicated around $60 \%$ is having positive effect, and from partial testing revealed three influencing factors: farmer motivation, self-ability, and marketing had a significant effect of 0.05 toward onion farmer success, while the role of the extension agent did not significantly influence the success of onion farmers. It can be concluded that onion are a potential commodity that could be developed in North Maluku.
\end{abstract}

\section{Keywords: Onion, farmer success}

\section{PENDAHULUAN}

Pertanian merupakan salah satu sektor yang memiliki peran penting dalam meningkatkan pendapatan masyarakat Indonesia karena sebagian besar penduduk di Indonesia bekerja sebagai petani. Upaya dalam penyediaan dan peningkatan produksi harus melalui konstratani atau gerakan pembangunan pertanian di tingkat kecamatan yang dilakukan dengan cara menyediakan informasi iklim, penguatan Simber Daya Manusia, penyediaan benih unggul, budidaya ramah lingkungan, penerapan teknologi, dukungan perairaan, dan alat mesin pertanian. Oleh karena itu peran dan kebijakan dari pemerintah sangat penting dalam mengatasi permasalahan dari pembangunan petanian. Kebijakan yang harus dilakukan oleh Pemerintah daerah adalah investasi dalam bidang pertanian harus kuat dengan membantu 
meningkatkan akses pasar, hal tersebut dilakukan untuk pembangunan pertanian sebagai salah satu upaya untuk pengentasan kemiskinan.

Berdasarkan data dari laporan kinerja (Direktorat Jendral Hortikultura, 2020) menunjukkan bahwa terdapat salah satu jenis tanaman holtikultura yang menjadi prioritas Nasional yaitu Bawang merah. Bawang merah merupakan salah satu komoditi sayuran unggulan yang sejak lama telah diusahakan oleh petani secara intensif. Komoditi sayuran ini termasuk dalam kelompok rempah tidak bersubtitusi yang berfungsi sebagai bumbu penyedap makanan serta bahan obat tradisional. komoditi ini juga merupakan sumber pendapatan dan kesempatan kerja yang memberikan kontribusi cukup tinggi terhadap perkembangan ekonomi wilayah (Badan Litbang Pertanian 2006).

Berdasarkan data (Kementrian Pertanian, 2019) luas panen bawang merah di Indonesia mencapai 156.779 Ha dengan jumlah produksi sebesar 1.503.436 ton. Lahan bawang merah terletak di 33 Provinsi di 175 Kabupaten. Provinsi Maluku Utara merupakan salah satu wilayah yang mempunyai potensi dalam pengembangan berbagai macam komoditas tanaman pangan, perkebunan, peternakan dan holtikultura yang dapat meningkatkan pendapatan petani.

Maluku Utara merupakah salah satu tempat sentra produksi bawang merah yaitu di Kota Tidore Kepulauan Kecamatan Oba, terdapat potensi produktifitas bawang merah yang sangat potensial karena hampir semua lahan pertanian di daerah ini cocok untuk usahatani bawang merah. Panen bawang merah cukup melimpah dengan luas panen bawang merah mencapai $22 \mathrm{Ha}$ dan jumlah produksi sebesar 989 ton. Berdasarkan data dari (Renstra, 2025) bahwa usaha pertanian yang dikembangkan di Kota Tidore Kepulauan terdiri dari beberapa subsektor, yaitu pertanian tanaman pangan, holtikultura, peternakan dan perikanan. Bawang merah merupakan salah satu tanaman holtikultura yang banyak diusahakan di Trans Tayawi Desa Koli Kosa Kecamatan Oba Kota Tidore Kepulauan.

Menurut Marsaoly (2020) usahatani bawang merah yang diusahakan oleh petani pada Unit Transmigrasi Koli Kecamatan Oba Kota Tidore Kepulauan merupakan sumber penghidupan utama dalam memperoleh pendapatan. Berdasarkan survei pendahuluan yang dilakukan menunjukkan bahwa Petani bawang merah di Trans Tayawi Desa Koli memiliki jumlah petani sebanyak 40 orang dengan luas lahan sebesar 0,25 sampai 3 ha dengan jumlah produksi $500 \mathrm{~kg}$ sampai 3 ton/tahun, harga jual bawang merah Rp 20.000 hingga Rp 45.000 per kg. Dalam proses budidaya bawang merah, petani di Tayawi menggunakan bibit sendiri dari berbagai jenis bibit bawang, hal ini dilakukan agar memudahkan petani pada saat penanaman atau proses pembudidayaan secara periodik.

Berdasarkan latar belakan tersebut maka penulis melakukan penelitian dengan judul "Faktor-Faktor yang Mempengaruhi Keberhasilan Petani Bawang Merah di Trans Tayawi Desa Koli Kecamatan Oba Kota Tidore Kepulauan" dengan tujuan untuk mengetahui faktor apa yang mempengaruhi keberhasilan petani bawang merah di Trans Tayawi Desa koli Kecamatan Oba Kota Tidore Kepulauan.

\section{METODE PENELITIAN}

Penelitian ini dilaksanakan pada tanggal 23-30 Desember 2021 di Trans Tayawi Desa Koli kecamatan Oba Kota Tidore Kepulauan. Jenis penelitian yang digunakan adalah deskriptif kuantitatif. Metode deskriptif yaitu metode yang mengetahui sifat serta hubungan yang lebih mendalam antara dua variabel dengan cara mengamati aspek-aspek tertentu secara lebih spesifik untuk memperoleh data yang sesuai dengan masalah yang ada pada tujuan penelitian Sugiyono (2019). Dalam penelitian ini analisis deskriptif digunakan untuk mengetahui faktorfaktor yang mempengaruhi keberhasilan petani bawang merah. Sedangkan Penelitian kuantitif adalah pendekatan yang digunakan untuk memecahkan permasalahan sosial atau kemanusiaan berdasarkan atas variabel yang tersusun dari teori-teori yang diukur dengan satuan angka-angka kuantitatif, serta dianalisis dengan prosedur statistik, guna menentukan apakah generalisasi dari teori-teori tersebut masih berlaku atau tidak (Sangadji dkk, 2020). Dalam 
penelitian ini analisis Kauntitatif digunakan untuk mengetahui faktor-faktor yang mempengaruhi keberhasilan petani bawang merah.

\section{HASIL DAN PEMBAHASAN \\ Responden berdasarkan Usia}

Data karakteristik responden berdasarkan usia petani yang menjalankan usaha tani bawang merah di Trans Tayawi Desa Koli Kecamatan Oba Kota Tidore Kepulauan dapat dilihat pada tabel dibawah ini:

Tabel 1. Data rata-rata umur responden di Trans Tayawi Desa Koli Kecamatan Oba Kota Tidore Kepulauan.

\begin{tabular}{cccc}
\hline No & Usia (Tahun) & Jumlah & Presentase (\%) \\
\hline 1 & $27-40$ & 14 & 35 \\
2 & $41-50$ & 20 & 50 \\
3 & $53-68$ & 6 & 15 \\
Total & & 40 & $100 \%$
\end{tabular}

Sumber : Data primer diolah (2021)

Hasil penelitian yang disajikan pada tabel di atas menunjukkan bahwa usahatani bawang merah banyak diusahakan oleh kelompok usia antara 41-50 tahun yaitu sebanyak 20 orang atau sebesar 50\%. Kelompok umur 41-50 tahun dapat dikatakan sebagai golongan umur yang masih produktif. Umur mempengaruhi kegiatan petani dalam melaksanakan kegiatan usahatani. Petani yang bekerja dalam usia produktif akan lebih baik dan maksimal dibandingkan dengan umur non produktif, selain itu umur juga dijadikan tolak ukur petani dalam bekerja (Ukkas 2017). Dengan kelompok umur responden yang produktf ini maka diharapkan petani memiliki kemampuan fisik yang kuat untuk tenaga kerja yang lebih besar terhadap usahataninya dilahan pekarangan sehingga diharapkan nantinya dapat meingkatkan produksi bawang merah dan menambah pendapatan petani. Kemudian diikuti dengan responden dari usia 27 - 40 sebanyak 14 orang atau sebesar 35\%. Berdasarkan umur responden pada penelitian ini menunjukkan bahwa minat generasi tua untuk menjadi petani bawang merah sangat rendah yaitu dari umur 53 - 68 orang atau sebesar $15 \%$.

\section{Responden Berdasarkan Pendidikan}

Data karakteristik responden berdasarkan pendidikan petani bawang merah Trans Tayawi Desa Koli Kecamatan Oba Kota Tidore Kepulauan dari tingkat pendidikan SD, SMP dan SMA dapat dilihat pada tabel dibawah ini:

Tabel 2. Data rata-rata responden berdasarkan pendidikan di Trans Tayawi Kecamatan Oba Kota Tidore kepulauan

\begin{tabular}{cccc}
\hline No & Pendidikan & Jumlah & Presentase (\%) \\
\hline 1 & SD & 24 & 60 \\
2 & SMP & 7 & 18 \\
3 & SMA & 9 & 22 \\
Total & & 40 & $100 \%$ \\
\hline
\end{tabular}

Sumber : Data Primer diolah (2021)

Hasil penelitian yang disajikan pada tabel di atas menunjukkan bahwa tingkat pendidikan responden merupakan tamatan SD, SMP dan SMA yaitu tamatan SD sebanyak 24 orang atau sebesar 60\%, SMP sebanyak 7 orang atau sebesar $18 \%$ dan tamatan SMA 
sebanyak 9 orang atau sebesar 22\%. Hal ini menunjukkan bahwa sebagian besar petani bawang merah lebih banyak pada tingkat pendidikan SD karena petani bawang merah mempunyai kelompok usaha tani yang terdiri dari ketua dan anggota, kemudian pengetahuan mereka tentang budidaya bawang merah yaitu dari petani yang lebih berpengalaman.

\section{Responden Berdasarkan Jenis Kelamin}

Data karakteristik responden berdasarkan jenis kelamin petani bawang merah di Trans Tayawi Desa Koli Kecamatan Oba Kota Tidore Kepulauan dapat dilihat pada tabel dibawah ini: Tabel 3. Data rata-Rata Responden Berdasarkan Jenis Kelamin di Trans Tayawi Kecamatan Oba Kota Tidore Kepulauan.

\begin{tabular}{cccc}
\hline No & Jenis & & \\
\hline 1 & Kelamin & Jumlah & Presentase(\%) \\
2 & Perempuan & 5 & 87,5 \\
Total & & 40 & 12,5 \\
& & $100 \%$ \\
\hline
\end{tabular}

Sumber: Data Primer Diolah (2021)

Hasil penelitian yang disajikan pada tabel di atas menunjukkan bahwa responden berjenis kelamin laki-laki sebanyak 35 orang atau sebesar $87 \%$ dan responden berjenis kelamin perempuan sebanyak 5 orang atau sebesar $5 \%$.

\section{Analisisi Regresi linier Berganda}

Penelitian ini menggunakan analisis regresi linier berganda dengan bantuan SPSS 16.0 untuk mengetahui kekuatan dan arah pengaruh variabel independen terhadap variabel dependen. Hasil uji regresi linier berganda dapat dilihat pada tabel dibawah ini:

Tabel 4. Hasil Analisis Regresi Linier Berganda

\begin{tabular}{lrll}
\hline $\begin{array}{l}\text { Model } \\
\text { Koef. (B) } \quad \text { T. hitung }\end{array}$ & Sig. T & & \\
\hline Constant & 1,517 & 0,832 & 0,411 \\
Peran Penyuluh & 0.000 & $-0,018$ & 0,986 \\
Motivasi Petani & 0,364 & 3,600 & 0,001 \\
Kemampuan Diri & 0,276 & 2,453 & 0,019 \\
Pemasaran & 0,246 & 4,435 & 0,020 \\
Ajd. R Square $=0,862$ & & & \\
F. Hitung $=62,148$ & & \\
Sig. F $=0,000$ & \\
N $=40$ & \\
Sumber: Data primer diolah dengan SPSS 16.0
\end{tabular}

Berdasarkan table di atas dapat diketahui hasil dari analisis regresi linier berganda dengan persamaan sebagai berikut: $Y=1,517+0,000 \times 1+0,0364 \times 2+0,276 \times 3+0,246 \times 4$ + e.

Berdasarkan persamaan regresi diatas, dapat diinterprestasikan sebagai berikut:

1. Jika $X_{1}, X_{2}, X_{3}$, dan $X_{4}$ bernilai nol maka $Y$ sebagai konstanta sebesar 1,517 yang menunjukkan bahwa besarnya pengaruh kinerja petani terhadap keberhasilan petani bawang merah. 
2. Berdasarkan persamaan regresi diatas menunjukkan bahwa variabel peran penyuluh $\left(\mathrm{X}_{1}\right)$ mempunyai arah regresi dengan nilai positif terhadap keberhasilan petani bawang merah yaitu b1 $=0,000$ dengan artian bahwa apabila peran penyuluh mengalami kenaikan 1 satuan maka pengaruh peran penyuluh dalam keberhasilan petani bawang merah mengalami penurunan sebesar 0,000 satuan.

3. Berdasarkan persamaan regresi diatas menunjukkan bahwa variabel motivasi petani (X2) mempunyai arah regresi positif dengan pengaruh motivasi petani terhadap keberhasilan petani bawang merah yaitu b1 $=0,364$. Dengan artian bahwa jika variabel motivasi petani mengalami peningkatan sebesar 1 satuan maka nilai variabel $(Y)$ akan mengalami peningkatan sebesar 0,364 satuan.

4. Berdasarkan persamaan regresi menunjukkan bahwa variabel kemampuan diri (X3) mempunyai arah regresi positif dengan pengaruh kemampuan diri terhadap keberhasilan petani bawang merah dengan nilai konstanta sebesar $=0,276$ yang berarti apabila variabel kemampuan diri mengalami peningkatan 1 satuan maka pengaruh kemampuan diri terhadap keberhasilan petani bawang merah mengalami kenaikan sebesar 0,276 satuan.

5. Berdasarkan persamaan regresi menunjukkan bahwa variabel pemasaran (X4) mempunyai arah regresi dengan pengaruh kinerja petani terhadap keberhasilan petani bawang merah dengan nilai konstanta $=0,246$ dengan artian bahwa apabila variabel pemasaran mengalami peningkatan 1 satuan maka pengaruh pemasaran terhadap keberhasilan petani bawang merah mengalami peningkatan sebesar 0,246 satuan.

\section{Uji Hipotesis}

\section{Uji Parsial (t-test)}

Uji parsial (t-test) adalah salah satu dari test statistik yang digunakan untuk menguji seberapa jauh dari variabel independen secara individual untuk menerangkan isi dari variabel dependen. Uji dilakukan dengan mengetahui nilai $t$ hitung dengan $t$ tabel dengan signifikan 0,05 . Hasil uji $t$ dapat dilihat pada tabel dibawah ini:

Tabel 5. Hasil Uji Parsial (t-test)

\begin{tabular}{lccc}
\hline \multicolumn{1}{c}{ Model } & t hitung & t tabel & Signifikan \\
\hline Peran Penyuluh (X1) & $-0,018$ & 1,305 & 0,986 \\
Motivasi Petani (X2) & 3,600 & 1,305 & 0,001 \\
Kemampuan diri (X3) & 2,453 & 1,305 & 0,019 \\
Pemasaran (X4) & 2,435 & 1,305 & 0,020 \\
\hline
\end{tabular}

Sumber: Data primer diolah dengan SPSS 16.0

Pengaruh peran penyuluh terhadap keberhasilan petani bawang merah Pengujian hipotesis yang pertama $\left(\mathrm{H}_{1}\right)$ pada penelitian ini yaitu peran penyuluh tidak berpengaruh terhadap keberhasilan petani bawang merah. Uji hipotesis pada penelitian ini menggunakan SPSS 16.0 dengan tingkat signifikan (a) 5\% atau 0,05. Dalam penelitian ini untuk mencari nilai distribusi $t$ yaitu menggunakan rumus $a=5 \%$ derajat kebebasan $(\mathrm{df})=\mathrm{n}-\mathrm{k}=40-4=$ 36, berdasarkan tabel t pada $a=5 \%$ maka dapat diperoleh nilai dari (df) sebesar 1,305.

Hasil uji $t$ diperoleh nilai $t$ hitung sebesar $-0,18$ dan $t$ tabel sebesar 1,305 hal tersebut menunjukkan bahwa $t$ hitung $<t$ tabel maka hipotesis ketiga $(\mathrm{H} 1)$ ditolak dengan nilai signifikan lebih besar dari tingkat signifikan yaitu $0,986>0,05$ sehingga dapat disimpulkan bahwa peran penyuluh tidak berpengaruh terhadap keberhasilan petani bawang merah dengan artian bahwa Ho diterima Ha ditolak. 
Pengaruh motivasi petani terhadap keberhasilan petani bawang merah. Pengujian hipotesis yang kedua $\left(\mathrm{H}_{2}\right)$ pada penelitian ini yaitu motivasi petani memberikan pengaruh positif dan signifikan terhadap keberhasilan petani bawang merah. Uji hipotesis pada penelitian ini menggunakan SPSS 16.0 dengan tingkat signifikan (a) 5\% atau 0,05. Dalam penelitian ini untuk mencari nilai distribusi $t$ yaitu menggunakan rumus $a=5 \%$ derajat kebebasan $(\mathrm{df})=\mathrm{n}-\mathrm{k}=40-4=36$, berdasarkan tabel $\mathrm{t}$ pada $\mathrm{a}=5 \%$ maka dapat diperoleh nilai dari (df) sebesar 1,305.

Hasil uji $t$ diperoleh nilai $t$ hitung sebesar 3,600 dan $t$ tabel sebesar 1,305 hal tersebut menunjukkan bahwa $t$ hitung $\geq t$ tabel maka hipotesis kedua $\left(\mathrm{H}_{2}\right)$ diterima dengan nilai signifikan lebih kecil dari tingkat signifikan yaitu $0,001 \leq 0,05$ sehingga dapat disimpulkan bahwa motivasi petani memberikan pengaruh terhadap keberhasilan petani bawang merah dengan artian $\mathrm{Ha}$ diterima $\mathrm{HO}$ ditolak.

Pengaruh kemampuan diri terhadap keberhasilan petani bawang merah. Uji hipotesis ketiga $(\mathrm{H} 3)$ pada penelitian ini adalah variabel kemampuan diri memberikan pengaruh positif dan signifikan terhadap keberhasilan petani bawang merah. Uji hipotesis pada penelitian ini menggunakan SPSS 16.0 dengan tingkat signifikan (a) $5 \%$ atau 0,05 . Dalam penelitian ini untuk mencari nilai distribusi t yaitu menggunakan rumus $a=5 \%$ derajat kebebasan $(\mathrm{df})=n-k$ $=40-4=36$, berdasarkan tabel $\mathrm{t}$ pada $\mathrm{a}=5 \%$ maka dapat diperoleh nilai dari ( $\mathrm{df}$ ) sebesar 1,305 .

Hasil uji $t$ diperoleh nilai $t$ hitung sebesar 2,453 dan $t$ tabel sebesar 1,305 hal tersebut menunjukkan bahwa $t$ hitung $\geq t$ tabel maka hipotesis ketiga $(\mathrm{H} 3)$ diterima dengan nilai signifikan lebih kecil dari tingkat signifikan yaitu $0,019<0,05$ sehingga dapat disimpulkan bahwa kemampuan diri berpengaruh terhadap keberhasilan petani bawang merah dengan artian bahwa Ha diterima HO ditolak.

Pengaruh pemasaran terhadap keberhasilan petani bawang merah. Uji hipotesis keempat (H4) pada penelitian ini adalah variabel pemasaran memberikan pengaruh positif dan signifikan terhadap keberhasilan petani bawang merah. Uji hipotesis pada penelitian ini menggunakan SPSS 16.0 dengan tingkat signifikan (a) $5 \%$ atau 0,05 . Dalam penelitian ini untuk mencari nilai distribusi $t$ yaitu menggunakan rumus $a=5 \%$ derajat kebebasan (df) $=n-k=40-4=36$, berdasarkan tabel $\mathrm{t}$ pada $\mathrm{a}=5 \%$ maka dapat diperoleh nilai dari (df) sebesar 1,305.

Hasil uji $t$ diperoleh nilai $t$ hitung sebesar 2,435 dan $t$ tabel sebesar 1,305 hal tersebut menunjukkan bahwa $t$ hitung $\geq t$ tabel maka hipotesis ketempat $(\mathrm{H} 4)$ diterima dengan nilai signifikan lebih kecil dari tingkat signifikan yaitu $0,020 \leq 0,05$ sehingga dapat disimpulkan bahwa pemasaran berpengaruh terhadap keberhasilan petani bawang merah dengan artian bahwa Ha terima Ho ditolak.

\section{Uji Simultan (F-test)}

Uji $\mathrm{F}$ digunakan untuk menguji dan mengetahui bagaimana pengaruh dari semua variabel yaitu peran penyuluh, motivasi petani, kemampuan diri dan pemasaran berpengaruh terhadap keberhasilan petani bawang, dan untuk menguji apakah model regresi yang telah digunakan mempunyai pengaruh yang signifikan atau non signifikan. Hasil uji simultan $F$ dapat dilihat pada tabel dibawah ini:

Tabel 6. Hasil Uji Simultan (F-test)

\begin{tabular}{lccc}
\hline \multicolumn{1}{c}{ Model } & Df & F & Signifikan \\
\hline Regresion & 4 & 62,148 & 0,000 \\
Residual & 35 & & \\
\hline \multicolumn{4}{l}{ Sumber: Data diolah dengan SPSS 16.0 }
\end{tabular}


Berdasarkan tabel 22 dapat diketahui bahwa nilai $f$ hitung sebesar 62,148 dan nilai probability signifikan $0,000 \leq 0,05$ sehingga dapat disimpulkan bahwa $X_{1}$ (peran penyuluh), $\mathrm{X}_{2}$ (motivasi petani), $\mathrm{X}_{3}$ (kemampuan diri) dan $\mathrm{X}_{4}$ (pemasaran) secara simultan atau secara bersama-sama memberikan pengaruh positif terhadap variabel $Y$ (keberhasilan petani bawang merah).

\section{Pembahasan Hasil Penelitian}

Pada penelitian ini terdapat tujuan penelitian yaitu untuk mengetahui pengaruh kinerja petani terhadap keberhasilan petani bawang merah.

\section{Pengaruh Peran Penyuluh Terhadap Keberhasilan Petani Bawang Merah}

Berdasarkan hasil pengujian hipotesis pertama $\left(\mathrm{H}_{1}\right)$ menunjukkan bahwa variabel $\left(\mathrm{X}_{1}\right)$ peran penyuluh tidak memberikan pengaruh terhadap keberhasilan petani bawang merah di Trans Tayawi. Dari hasil pengujian yang telah dilakukan dengan SPSS 16.0 diperoleh nilai $t$ hitung sebesar $-0,018$ yang menunjukkan nilai $t$ hitung $\leq \mathrm{t}$ tabel $(-0,018 \leq 1,305)$ berdasarkan uji signifikan variabel peran penyuluh sebesar 0,986 hal ini berarti bahwa diatas 0,05 yang menunjukkan $\mathrm{H} 1$ ditolak sehingga dapat diketahui bahwa variabel peran penyuluh tidak memberikan pengaruh positif dan signifikan terhadap keberhasilan petani bawang merah.

Berdasarkan hasil wawancara yang telah dilakukan kepada 40 responden, mengatakan bahwa jumlah penyuluh di Kecamatan Oba hanya satu orang, dengan melakukan tugas menyuluhnya ada di beberapa desa tidak hanya berfokus pada Trans Tayawi, sehingga menimbulkan kurangnya kinerja yang optimal dalam melakukan pelatihan, dan membantu petani dalam mendapatkan modal. Selain itu hasil wawancara petani mengatakan bahwa ditahun 2020 penyuluh melakukan kunjungan kepada petani hanya sekali dalam satu minggu bahkan hanya sebulan sekali sehingga menimbulkan ketergantungan antara petani terhadap penyuluh.

Penyuluh pertanian diharapkan untuk menciptakan kemandirian dan memposisikan petani sebagai petani yang berkualitas dalam bidang agribisnis, agar petani dapat berusahatani dengan baik dan layak dengan sumber daya lokal yang ada disekitar petani. Hal ini sangat membutuhkan kinerja penyuluh petanian yang baik pada pelaksanan tugas pokok dan fungsi penyuluh pertanian dan merencanakan, mengorganisasikan, mengawasi, dan mengevaluasi program penyuluh pertanian.

Penelitian ini didukung oleh penelitian (Nurlina Harahap et al, 2020) mengatakan bahwa peran penyuluh pertanian tidak memberikan pengaruh positif dan signifikan terhadap keberhasilan petani karena kegiatan penyuluh dalam proses pemberdayaan petani bawang merah hanya terbatas dalam bentuk pengembangan usaha yang produktif.

\section{Pengaruh Motivasi Petani Terhadap Keberhasilan Petani Bawang Merah}

Berdasarkan hasil pengujian hipotesis kedua $\left(\mathrm{H}_{2}\right)$ menunjukkan bahwa variabel $\left(\mathrm{X}_{2}\right)$ motivasi petani memberikan pengaruh positif dan signifikan terhadap keberhasilan petani bawang merah. Hasil pengujian yang telah dilakukan dengan SPSS 16.0 diperoleh nilai $t$ hitung sebesar 3,600 yang menunjukkan bahwa nilai $t$ hitung $\geq t$ tabel $(3,600 \geq 1,304)$. Hasil pengujian signifikan variabel motivasi petani sebesar 0,001 hal ini berarti dibawah 0,05 yang menunjukkan bahwa hipotesis $\mathrm{H}_{2}$ diterima sehingga dapat diketahui bahwa variabel $\left(\mathrm{X}_{2}\right)$ motivasi petani memberikan pengaruh yang positif dan signifikan terhadap keberhasilan petani bawang merah.

Berdasarkan hasil wawancara kepada 40 responden petani bawang merah di Trans Tayawi Desa Koli bahwa petani bawang merah mempunyai motivasi yang tinggi dengan keinginan dan harapan untuk dapat memenuhi kebutuhan primer, sekunder, peningkatan pendapatan, punya tabungan dan kesejahteraan keluarga meningkat dalam hidupnya. Petani juga memiliki keinginan untuk dapat mememenuhi kebutuhan dalam menjalin hubungan 
dengan sesamanya, bekerja sama dengan orang lain, serta mengembangkan diri, berprestasi dan ingin maju dalam hidupnya.

Penelitian ini sejalan dengan teori Hasibun 2007 motivasi adalah dorongan dasar yang menggerakkan seseorang bertingkah laku. Dorongan ini berada pada diri seseorang yang menggerakkan untuk melakukan sesuatu yang sesuai dengan dorongan yang ada dalam dirinya. Oleh karena itu, perbuatan seseorang yang didasarkan atas motivasi tertentu mengandung tema sesuai dengan motivasi yang mendasarinya. Memotivasi maksudnya mendorong seseorang untuk mengambil tindakan tertentu.

Penelitian ini juga didukung oleh penelitian yang dilakukan oleh (Natali, 2019) yang menyatakan bahwa motivasi berpengaruh terhadap keberhasilan usahatani karena sebagian besar petani sangat mengharapkan penghasilan yang besar dari usahataninya dan mampu meningkatkan status sosialnya di masyarakat.

\section{Pengaruh Kemampuan Diri Terhadap Keberhasilan Petani Bawang Merah}

Berdasarkan hasil pengujian hipotesis ( $\left.\mathrm{H}_{3}\right)$ bahwa variabel kemampuan diri berpengaruh positif dan signifikan terhadap keberhasilan petani bawang merah. Hasil pengujian yang telah dilakukan dengan SPSS 16.0 diperoleh nilai $t$ hitung sebesar 2,453 yang menunjukkan bahwa nilai $\mathrm{t}$ hitung $\geq \mathrm{t}$ tabel $(2,453 \geq 1,304)$. Hasil pengujian signifikan variabel kemampuan diri sebesar 0,019 hal ini berarti dibawah 0,05 yang menunjukkan bahwa hipotesis $\left(\mathrm{H}_{3}\right)$ diterima, sehingga dapat diketahui bahwa variabel kemampuan diri memberikan pengaruh positif dan signifikan terhadap keberhasilan petani bawang merah.

Berdasarkan hasil wawancara yang telah dilakukan kepada 40 responden petani bawang merah dapat diketahui bahwa petani bawang merah di Trans Tayawi memiliki pengetahuan dalam budidaya, pengolahan lahan, penanganan panen dan pascapanen serta pengetahuan petani untuk mengatasi serangan hama dan penyakit pada tanaman bawang merah. Selain itu pengalaman petani dalam usahatani bawang merah rata-rata diatas $5-10$ tahun. Karena pada umumnya semakin tinggi pengalaman petani dalam pengelolaan usahatani maka semakin tinggi pula pengetahuan yang dimiliki dalam usahatani. Dari hasil yang diperoleh jawaban responden sangat setuju sebesar 16 responden atau $40 \%$ dan setuju sebesar 24 responden atau $60 \%$.

Penelitian ini sejalan dengan teori (Timonthy, 2009) yang mengatakan bahwa kemampuan adalah kesanggupan atau kecakapan seorang individu dalam menguasai suatu keahlian dan digunakan untuk mengajarkan beragam tugas dalam suatu pekerjaan. Teori tersebut menjelaskan bahwa kemampuan diri atau keahlian seseorang dapat mempengaruhi keberhasilannya.

\section{Pengaruh Pemasaran Terhadap Keberhasilan Petani Bawang Merah}

Berdasarkan hasil pengujian hipotesis $(\mathrm{H} 4)$ bahwa variabel pemasaran berpengaruh positif dan signifikan terhadap keberhasilan petani bawang merah. Hasil pengujian yang telah dilakukan dengan SPSS 16.0 diperoleh nilai t hitung sebesar 4,707 yang menunjukkan bahwa nilai $\mathrm{t}$ hitung $\geq \mathrm{t}$ tabel $(4,707 \geq 1,304)$. Hasil pengujian signifikan variabel pemasaran sebesar $0,020$, hal ini berarti dibawah 0,05 yang menunjukkan bahwa hipotesis ( $\mathrm{H} 4)$ diterima, sehingga dapat diketahui bahwa variabel pemasaran memberikan pengaruh positif dan signifikan terhadap keberhasilan petani bawang merah.

Pada penelitian ini bawang merah di Trans Tayawi termasuk pada struktur pasar persaingan sempurna karena terdapat banyak penjual dan pembeli, barang yang diperjualbelikan bersifat homogen serta faktor produksi bebas bergerak. Berdasarkan hasil wawancara kepada 40 responden menunjukkan bahwa petani bawang merah di Trans Tayawi memiliki dua saluran pemasaran yaitu :

1. Petani pedagang $\rightarrow$ pengecer konsumen (saluran 1)

Pada saluran ini petani menjual bawang merah ke pedagang pengecer untuk dijual di pasar Bale, Weda, Tidore, Morotai dan Ternate. 
2. Petani $\longrightarrow$ konsumen akhir (saluran 2)

Pada saluran ini petani menjual bawang merah langsung ke masyarakat pada desa terdekat yaitu di Trans Tayawi Woda dan Koli Kosa.

Pemasaran bawang merah merupakan kegiatan penyampaian komoditi bawang merah dari pedagang pengecer, pedagang antar kota dan konsumen akhir. Penyaluran bawang merah dari petani ke konsumen lebih dari satu saluran pemasaran yang melibatkan lembaga yang berbeda-beda, saluran pemasaran dapat dipilih oleh petani, artinya mereka dapat menentukan saluaran pemasaran mana yang paling menguntungkan sehingga dapat menambah pendapatan keluarga dan ada sebagian kecil untuk konsumsi rumah tangga. Dalam meningkatkan pendapatan petani sangat dipengaruhi oleh pemasaran hasil produksi dan harga yang berlaku dengan tujuan agar semua pihak yang terlibat dapat memperoleh keuntungan.

Penelitian ini didukung oleh penelitian dari (Nurlina Harahap et al, 2020) mengatakan bahwa variabel pemasaran memberikan pengaruh positif terhadap keberhasilan petani hal ini disebabkan karena adanya ketidakstabilan harga dapat menyebabkan kerugian karena modal yang digunakan sangat banyak sedangkan harga dipasaran rendah.

\section{KESIMPULAN}

Berdasarkan hasil analisis dan pembahasan yang telah dilakukan dalam penelitian ini, maka dapat disimpulkan sebagai berikut: 1.) Peran penyuluh tidak berpengaruh terhadap keberhasilan petani karena penyuluh pertanian dalam melakukan kunjungan belum dilakukan secara maksimal; 2.) Motivasi petani berpengaruh terhadap keberhasilan petani karena semakin tinggi motivasi petani maka dapat meningkatkan keberhasilannya sebagai petani bawang merah; 3.) Kemampuan diri berpengaruh positif dan signifikan terhadap keberhasilan petani karena rata-rata petani bawang merah memiliki pengalaman usahatani di atas $5-10$ tahun. Semakin tinggi pengalaman petani dalam pengelolaan usahatani maka semakin tinggi pula pengetahuan

\section{UCAPAN TERIMA KASIH}

Terima kasih kepada Bapak Dr. Natal Basuki, S.Pt., M.Si dan Mila Fatmawati, S.E., M.Sa yang telah membimbing saya sampai bisa menyelesaikan penelitian ini. Terima kasih juga kepada Bapak Haris Mahmud yang selalu memberikan support dan saran yang membangun dalam penelitian ini, tak lupa pula ucapan terima kasih kepada Kantor Badan Pusat Statistik Kota Tidore Kepualauan dalam pemberian data-data untuk penelitian ini.

\section{DAFTAR PUSTAKA}

Badan Litbang Pertanian (2006). Potensi Penanaman Tanaman Serealia dan Sayuran.

Badan Pusat Statistik (2019). Kota Tidore Kepulaun Dalam Angka. BPS Kota Tidore Kepulauan BR Pinem \& Desi Natal (2019). Pengaruh Karakteristik Petani, Kompetensi, Motivasi Dan Produktivitas Terhadap Keberhasilan Usaha Petani Jeruk. Jurnal. Unversitas Sanata Dharma Yogyakarta.

Kementrian Pertanian Direktorat Jendral Hortikultura (2020). Laporan Kinerja Tahun Anggaran 2020.http://hortikultura.pertani an.go.id.laporan-kinerja-ditjen- hortikulturaTA2020.pdf.

Kementrian Pertanian Republik Indonesia (2019). Statistik Data Lahan Pertanian.

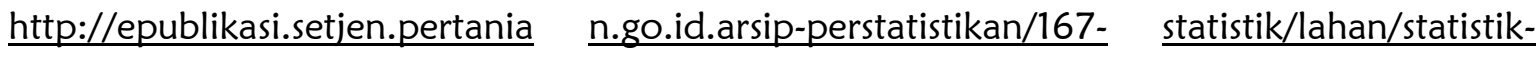
data- tahan-pertanian-no-6-2015- 2019 
Marsaoly, H. A., Sangadji, S. S., \& Sumartono, E. (2020). Analisis Profitabilitas Usaha Tani Bawang Merah pada Unit Transmigrasi (Trans Koli). AGRITEPA: Jurnal IImu dan Teknologi Pertanian, 7(2), 142-151.

Nurlina Harahap, Ameilia Zuliyanti SiregarYusra Muharami Lestari dan Hamdan (2020). Faktor-Faktor yang Mempengaruhi Keberhasilan Petani Penangkar Bawang Merah. Jurnal Agrica Ekstensia.Vol.14.No.1 Universitas Sumatera Utara.

Robins Stephen P. Judge \& Timonthy, A Judge (2009), Perilaku Organisasi Bukul, Jakarta Salemba Empat.

Sangadji, S. S., Kariadi, M. T., \& Rachman, S. (2020). The Effectivity of Nutmeg Processing and Packaging Reformulation Activity in Increasing The Public Welfare in Jaya Village of Tidore Islands. Agro Bali: Agricultural Journal, 3(2), 118-126.

Sugiyono. (2019) Metode Penelitian Kuantitatif, Kualitatif, dan R $\square$ D. Bandung. ALFABETA

Ukkas Imran (2017). Faktor-Faktor Yang Mempengaruhi Produktifitas Tenaga Kerja Di Industri Kecil Kota Palopo. Program Study Manajemen Sekolah Tinggi Ilmu Ekonomi Muhammadiyah palopo. 